\title{
OCJENE I OČEKIVANJA MENADŽERA U HRVATSKOM USLUŽNOM SEKTORU ODREĐENE VLASNIŠTVOM: DA ILI NE?
}

\author{
MANAGERS' ASSESSMENTS AND EXPECTATIONS \\ IN CROATIAN SERVICES SECTOR DETERMINED \\ BY OWNERSHIP: YES OR NO?
}

SAŽETAK: Uslužni sektor u Hrvatskoj je visoko zastupljen u strukturi BDP-a. Prognoziranje promjena u tome važnom sektoru nacionalnoga gospodarstva moguće je provesti, između ostaloga, korištenjem rezultata konjunkturnih testova. Iako su konjunkturni testovi usklađeni na razini Europske unije (EU), heterogenost uslužnoga sektora ostavila je mogućnosti odstupanja u metodologiji provođenja po zemljama članicama EU. Područja u kojima su prisutna javna i polu-javna poduzeća su posebna po svojim obilježjima i kao takva se mogu isključiti iz konjunkturnog testa. Na tragu toga je postavljena, a zatim i potvrđena, istraživačka hipoteza rada da su vlasništvo (s jedne strane) i sve ostale varijable u konjunkturnom testu uslužnoga sektora RH (s druge strane) statistički nezavisne varijable. Iz navedenoga slijedi da nije nužno iz hrvatskoga testa isključiti područja obrazovanja i djelatnost zdravstvene zaštite i socijalne skrbi. U istraživanju su korišteni podaci Centra za poslovna istraživanja Privrednog vjesnika - Zagreb za konjunkturni test proveden krajem lipnja i početkom srpnja 2016. godine na uzorku 90 menadžera uslužnoga sektora.

KLJUČNE RIJEČI: konjunkturni testovi, uslužni sektor, vlasništvo, hi-kvadrat test, statistička nezavisnost.

SUMMARY: The service sector in Croatia is highly represented in the structure of GDP. Forecasting changes in this important sector of the national economy can be carried out, among other things, using the Business survey results. Although the Business surreys are harmonised at the EU level, the heterogeneity of the service sector has left a possibilities for variations in the survey methodology by Member States. Areas where public and semi-public companies dominate are special by its nature and as such can be excluded from the Business survey. In accordance with this, the research hypothesis is formulated and then confirmed, that the ownership (on one side) and all other variables in the Business surveys of the Croatian service sector (on the other side) are statistically independent variables. It follows that it is not necessarily to exclude education and health care and social welfare 
from the Croatian Business survey. Data source was the Business survey by Business Research Centre "Privredni vjesnik-Zagreb" conducted in the end of June and early in July 2016, on a sample of 90 managers in the service sector.

KEY WORDS: business surveys, the service sector, ownership, chi-square test, statistical independence.

\section{UVOD}

U vrijeme kada Hrvatska bilježi kontinuirani rast BDP-a, kada je optimizam zamijenio višegodišnje razdoblje pesimizma hrvatskih gospodarstvenika, njihove ocjene i očekivanja se pokazuju kao vrlo koristan izvor informacija za praćenje i prognoziranje gospodarskih kretanja kako na makro, tako i na mikro razini. Naime, BDP se prema podacima hrvatskog Državnog zavoda za statistiku kontinuirano povećava od 2015. godine. Tako se u drugome tromjesečju 2016. godine povećao za 2,8 posto u odnosu na isto razdoblje prethodne godine (http://www.dzs.hr). Uslijedila su još dva povećanja u trećemu i četvrtome tromjesečju 2016. godine što je vrlo uspješno bilo najavljivano nekoliko mjeseci unaprijed, pokazateljima hrvatskih konjunkturnih testova.

Ocjene i očekivanja gospodarstvenika prate se kontinuirano u zemljama članicama EU i njenim potencijalnim članicama u okviru Harmoniziranog programa konjunkturnih testova i testova potrošača (engl. The Joint Harmonised EU Programme of Business and Consumer Surveys, BCS programm; European Commission, 1997.). One su izvor informacija za uspješne makroekonomske prognoze na razini pojedinih nacionalnih gospodarstava i njihovih sektora, na razini eurozone i na razini Europske unije u cjelini. Veliki broj teorijskih i empirijskih istraživanja potvrđuje njihova prediktivna svojstva (DGECFIN, 2017; Baláž i Nežinský, 2016; Astolfi, M. et al., 2016; Lehmann i Wohlrabe, 2016; Papamichael i Pashourtidou, 2016; Cesaroni i Iezzi, 2015; Antonides, 2008; Claveria, et al., 2005. i dr.).

Konjunkturni testovi i testovi potrošača (engl. Business and Consumer Survey, BCS) provode se u prerađivačkoj industriji, trgovini, građevinarstvu, uslužnome sektoru te među potrošačima. Kako bi rezultati konjunkturnih testova bili usporedivi po zemljama članicama EU, nastoji se postići što veća razina njihove harmoniziranosti, ali ona nije postignuta u potpunosti. Tako je, između ostaloga, u uslužnome sektoru koji postaje s vremenom sve značajniji kako u nacionalnome, tako i u europskome gospodarstvu, još uvijek različit obuhvat područja odnosno odjeljaka po NACE Rev. 2 klasifikaciji (Eurostat, 2008.). Opće je stajalište Europske komisije da područja uslužnoga sektora u kojima prevladavaju javna poduzeća u kojima su ocjene i očekivanja menadžera velikim dijelom ograničena propisima što znači da ne odražavaju u potpunosti vlastite percepcije menadžera, treba isključiti iz istraživanja ili provoditi zasebno istraživanje u tim područjima kao što se čini za financijske usluge i usluge osiguranja.

Iako se konjunkturni testovi provode, pored uslužnoga sektora, u prerađivačkoj industriji, trgovini i građevinarstvu, u radu se analiza povezanosti vlasništva i ostalih varijabli provodi upravo za uslužni sektor koji je visoko zastupljen u strukturi hrvatskoga BDP-a (50,2 \% 2014. godine, prikazano u tablici 1.). Uvažavajući značaj ovih istraživanja i aktualnu gospodarsku situaciju u Hrvatskoj, a temeljem dostupnih podataka, postavljena je istraživačka hipoteza rada da su vlasništvo (s jedne strane) i sve ostale varijable u konjunktur- 
nom testu uslužnoga sektora RH (s druge strane) statistički nezavisne varijable. Navedena hipoteza provjerava se odgovorom na istraživačko pitanje: jesu li vlasnička struktura i ocjene i očekivanja menadžera statistički nezavisne varijable $u$ hrvatskom konjunkturnom testu u uslužnome sektoru. Odnosno, treba li iz ovih hrvatskih konjunkturnih testova isključiti područja obrazovanja, djelatnosti zdravstvene zaštite i socijalne skrbi i javne uprave i obrane zbog njihove specifičnosti u području javnih usluga. U znanstvenoj i stručnoj literaturi ova tema dosada nije posebno istraživana. Iako je uslužni sektor vrlo heterogen, preporuka unificiranosti istraživanja Ureda za ekonomske i financijske poslove Europske unije (engl. Directorate-General for Economic and Financial Affairs, DG ECFIN) prezentirana u Harmoniziranom programu konjunkturnih testova i testova potrošača, uglavnom se primjenjuje u zemljama članicama EU. Ovaj rad je iskorak u ispitivanju povezanosti ocjena i očekivanja menadžera u uslužnome sektoru RH, s jedne strane, i vlasničke strukture, s druge strane, kako bi se provjerila opravdanost predloženoga isključivanja pojedinih područja iz konjunkturnih istraživanja. Rezultati istraživanja su korisni svima onima koji svoje odluke temelje, između ostaloga, na rezultatima konjunkturnih testova.

Istraživanje ima teorijski i empirijski dio. U teorijskome dijelu koji obuhvaća prvo i drugo poglavlje rada, objašnjeni su osnovni pojmovi konjunkturnih testova u Europskoj uniji i u Republici Hrvatskoj. Posebno su istaknute specifičnosti ovih istraživanja za Hrvatsku. U trećemu poglavlju je opisano empirijsko istraživanje. Ono je provedeno korištenjem rezultata konjunkturnog testa za drugo tromjesečje 2016. godine na uzorku 90 menadžera u uslužnome sektoru Hrvatske. Konjunkturni test je proveden krajem lipnja i početkom srpnja 2016. godine, a proveo ga je Centar za poslovna istraživanja Privrednog vjesnika Zagreb.

\section{KONJUNKTURNI TESTOVI EUROPSKE UNIJE I REPUBLIKE HRVATSKE}

Konjunkturni testovi (engl. Business Survey) su dio cjelovitih anketnih istraživanja zajednički nazvanih konjunkturni testovi i testovi potrošača (ankete pouzdanih poduzeća i potrošača).

Prvi konjunkturni test u Europi proveo je IFO Institut iz Münchena (IFO - Institut für Wirtschaftsforschung) 1949. godine, zatim, 1951. godine INSEE (Institut National de la Statistique et des Etudes Economiques) u Francuskoj i ISCO (Instituto Nazionale per lo Studio della Congiuntura) u Italiji (European Commission, 2017a). U cilju usklađivanja istraživanja i njihove međunarodne usporedivosti, 1962. godine definiran je Harmonizirani program konjunkturnih testova i testova potrošača Europske unije (BCS program).

Prvo istraživanje provedeno je u prerađivačkoj industriji, a zatim u trgovini na malo, građevinarstvu i uslužnome sektoru. Uočavanjem posebne važnosti, a i određenih specifičnosti područja financijskih djelatnosti, upravo je ono isključeno iz istraživanja uslužnoga sektora 2007. godine i za njega se provode posebna istraživanja kako bi se lakše uočile i pratile promjene samo u tome važnom segmentu gospodarstva. Cilj ovoga izdvajanja bio je postići reprezentativne rezultate za EU i Euro područje. Istraživanje je najprije provedeno u jedanaest država članica: Austrija, Češka, Njemačka, Španjolska, Francuska, Italija, Luksemburg, Nizozemska, Poljska, Švedska i Velika Britanija (European Commission, 2017a). 
Rezultati europskih konjunkturnih testova objavljuju se na mjesečnoj razini na internetskim stranicama Europske komisije (http://ec.europa.eu/economy_finance/db_indicators; European Commission, 2017b).

\subsection{Konjunkturni testovi Europske unije u uslužnome sektoru}

Sektor usluga je heterogeni sektor. Pokrivenost toga sektora konjunkturnim testovima nije jedinstvena u svim zemljama članicama EU (kako je detaljno opisano u European Commision, 2017a). Po preporuci Europske komisije odnosno po BCS programu, sektor usluga uključuje 37 odjeljaka prema klasifikaciji NACE Rev. 2 po područjima $\mathrm{H}$ do $\mathrm{N}$ i R do S. Područje G - Trgovina na veliko i na malo: popravak motornih vozila i motocikala pokriveno je zasebnim testovima. Područje K - Financijske djelatnosti i djelatnosti osiguranja (odjeljci 64-66), kao što je već navedeno, 2007. godine izdvojeno je također kao zasebno područje u istraživanju.

Javne usluge (O - Javna uprava i obrana: obvezno socijalno osiguranje, P - Obrazovanje, Q - Djelatnost zdravstvene zaštite i socijalne skrbi) su isključene iz istraživanja. Ta su područja ipak specifična. Smatra se da su u tim područjima ocjene i očekivanja menadžera jednim dijelom ograničene pravnom regulativom i ostalim elementima koji ih ne čine potpuno individualnima i slobodnima. Zbog homogenosti zaključaka istraživanja u sektoru, preporuka je da se ta područja isključe iz istraživanja. Uglavnom se to radi o područjima u kojima su poslovni subjekti u isključivo ili u dominantno javnome vlasništvu.

Prema BCS programu, tri su skupine u koje su razvrstani odjeljci uslužnoga sektora. U prvoj skupini je 17 odjeljaka $(49,52,55,56,61,62,68,69,70,71,73,74,77,78,79,81$ i 82). Ti odjeljci pokrivaju oko $70 \%$ ukupne uslužne aktivnosti (prema: European Commision, 2017a, p. 10-11). Oni su uključeni u istraživanja svih zemalja članica EU. U drugoj skupini su odjeljci koji pokrivaju oko $10 \%$ ukupne aktivnosti u uslužnome sektoru $(50,51$, $53,58,59,60,63,72,80,92,93,95$ i 96). Njih je iz svojih istraživanja isključilo između 6 i 11 nacionalnih instituta. U trećoj skupini su odjeljci koji čine oko $20 \%$ ukupne aktivnosti uslužnoga sektora i koje je iz istraživanja isključila većina nacionalnih instituta, a uglavnom se odnose na financijske usluge $(64,65$ i 66, 75, 90, 91 i 94).

\subsection{Konjunkturni testovi Republike Hrvatske u uslužnome sektoru}

Hrvatske konjunkturne testove postavio je Centar za poslovna istraživanja Privrednog vjesnika uz financijsku potporu Hrvatske gospodarske komore (Čižmešija, 2008.), po metodologiji IFO instituta 1995. godine i to najprije u prerađivačkoj industriji, a zatim u trgovini i građevinarstvu, a od 2008. godine u uslužnome sektoru. Ova se istraživanja i danas kontinuirano provode na kvartalnoj razini, a rezultati se objavljuju u tjedniku Privredni vjesnik. Uključuju i sektore s dominantnim državnim vlasništvom. Također se, od svibnja 2008. godine, rezultati hrvatskih konjunkturnih testova objavljuju i na stranicama Europske komisije kao mjesečni podaci, ali oni ne uključuju područja javnih usluga $(\mathrm{O}, \mathrm{P}$ i Q).

Istraživanja se provode putem anketnih upitnika na uzorku menadžera pojedinih gospodarskih sektora. Anketni upitnici imaju desetak pitanja koja uglavnom imaju tri do šest ponuđenih odgovora (modaliteta). Različitim analitičkim metodama kvalitativne ocjene i 
očekivanja menadžera se preračunavaju u numeričke pokazatelje koji imaju svojstvo vodećih pokazatelja u prognoziranju makroekonomskih kretanja, a pored toga su raspoloživi znatno ranije od istovrsnih ili sličnih pokazatelja službene statistike.

Pokrivenost sektora trebala bi (u teorijskome smislu) biti što veća. Međutim, europska istraživanja, koja se provode po klasifikaciji NACE Rev. 2. su zbog specifičnosti ili njihove posebne važnosti, neka područja klasifikacije djelatnosti isključila iz obuhvata, ali se ista i dalje analiziraju u tromjesečnim hrvatskim konjunkturnim testovima. Djelatnosti odnosno područja u uslužnome sektoru po NKD-u 2007. ${ }^{1}$ obuhvaćena u hrvatskome tromjesečnom istraživanju Privrednog vjesnika i Hrvatske gospodarske komore te postotni udio svakoga od područja u BDP-u, dana su u tablici 1.

Tablica 1. Struktura BDP-a RH, 2014. godine, tekuće cijene (ESA 2010)

\begin{tabular}{|l|c|}
\hline Područje & \%-tni udio u BDP-u \\
\hline $\begin{array}{l}\text { E Opskrba vodom; uklanjanje otpadnih voda, gospodarenje } \\
\text { otpadom te djelatnosti sanacije okoliša* }\end{array}$ & 1,3 \\
\hline H Prijevoz i skladištenje & 3,9 \\
\hline I Djelatnosti pružanja smještaja te pripreme i usluživanja hrane & 4,4 \\
\hline J Informacije i komunikacije & 3,7 \\
\hline K Financijske djelatnosti i djelatnosti osiguranja** & 5,6 \\
\hline L Poslovanje nekretninama & 8,8 \\
\hline M Stručne, znanstvene i tehničke djelatnosti & 5,1 \\
\hline N Administrativne i pomoćne uslužne djelatnosti & 1,8 \\
\hline O Javna uprava i obrana; obvezno socijalno osiguranje* & 4,9 \\
\hline P Obrazovanje* & 3,9 \\
\hline Q Djelatnosti zdravstvene zaštite i socijalne skrbi* & 4,0 \\
\hline R Umjetnost, zabava i rekreacija & 1,4 \\
\hline S Ostale uslužne djelatnosti & 1,4 \\
\hline Ukupno & 50,2 \\
\hline
\end{tabular}

Napomena: područja označena * nisu uključena u harmonizirane konjunkturne testove EU, ** istraživanje se provodi izdvojeno iz uslužnoga sektora.

Izvor: Priopćenje DZS-a 12.1.4/30. rujna 2016., http://www.dzs.hr [pristupano 13.1.2017.].

Djelatnosti javne uprave i obrane $(\mathrm{O})$ nisu obuhvaćene hrvatskim tromjesečnim konjunkturnim testovima Privrednog vjesnika.

Prema podacima Privrednog vjesnika za šest tromjesečja 2015. i 2016. godine (tablica 2.) može se uočiti da u strukturi anketiranih poslovnih subjekata dominiraju oni u potpuno privatnome vlasništvu, ali da je relativni udio većinskoga državnog vlasništva također visok i kreće se između $17,20 \%$ u prvome tromjesečju 2016. godine i $23,15 \%$ u prvome tromjesečju 2015. godine. Stoga će se u empirijskome dijelu istraživanja ispitati jesu li ocjene i očekivanja menadžera i vlasništvo statistički nezavisne varijable.

U Hrvatskoj se primjenjuje NKD 2007. To je nacionalna inačica europske klasifikacije NACE Rev. 2 i s njom je potpuno usklađena na svim razinama. 
Tablica 2. Struktura anketiranih poslovnih subjekata u uslužnome sektoru RH prema vlasništvu u šest tromjesečja tijekom 2015. i 2016. godine

\begin{tabular}{|l|c|c|c|c|c|c|}
\hline \multirow{2}{*}{ Vlasništvo } & \multicolumn{4}{|c|}{ 2015. } & \multicolumn{2}{c|}{ 2016. } \\
\cline { 2 - 7 } & I. & II. & III. & IV. & I. & II. \\
\hline Potpuno privatno & 67,59 & 74,04 & 76,72 & 71,26 & 78,49 & 65,56 \\
\hline Većinsko privatno & 9,26 & 6,73 & 4,31 & 5,75 & 4,30 & 10,00 \\
\hline Većinsko državno & 23,15 & 19,23 & 18,97 & 22,99 & 17,20 & 24,44 \\
\hline Ukupno & 100 & 100 & 100 & 100 & 100 & 100 \\
\hline
\end{tabular}

Izvor: izračun autora, prema podacima Centra za poslovna istraživanja Privrednog vjesnika, Zagreb.

\section{EMPIRIJSKO ISTRAŽIVANJE: REZULTATI I DISKUSIJA}

Empirijsko istraživanje provedeno je korištenjem podataka anketnoga istraživanja u okviru tromjesečnih konjunkturnih testova u uslužnome sektoru Hrvatske. Podatke prikuplja Centar za poslovna istraživanja Privrednog vjesnika. ${ }^{2}$

U radu su analizirani odgovori anketiranih menadžera 90 tvrtki uslužnoga sektora u Hrvatskoj (u skladu s NKD 2007, kako je dano u tablici 1.). Anketa je provedena krajem lipnja i početkom srpnja 2016. godine. Rezultati i tumačenje dinamike kretanja pokazatelja konjunkturne klime u uslužnome sektoru kao i u ostalim sektorima uključenim u tromjesečne konjunkturne testove Hrvatske, na uobičajen način su prezentirani u Privrednom vjesniku (Čižmešija, 2016.). U testiranju nezavisnosti dviju kvalitativnih varijabli u tablici kontingence korišten je Hi-kvadrat test kao najčešće korišteni neparametarski test. Testiranje je provedeno na razini značajnosti testa $5 \%$.

Tri su skupine pitanja (varijabli): ocjena sadašnjih kretanja, planovi i očekivanja i posebna pitanja koja se odnose na vlasničku strukturu i ocjenu likvidnosti. U anketnome upitniku je ukupno devet pitanja. Pitanja se odnose na kvalitativne varijable. U obradi i prezentiranju rezultata korištene su sljedeće kratice naziva varijabli:

$1 \mathrm{PP}$ - ocijenjeno poslovanje u prethodna tri mjeseca

Modaliteti: poboljšanje, ne mijenjanje, pogoršanje

2PP - ocijenjena potražnja u prethodna tri mjeseca

Modaliteti: povećanje, ne mijenjanje, smanjenje

3OP - očekivana potražnja u sljedeća tri mjeseca

Modaliteti: povećanje, ne mijenjanje, smanjenje

4PZ - ocjena zaposlenosti u prethodna tri mjeseca

Modaliteti: povećanje, ne mijenjanje, smanjenje

5OZ - očekivana zaposlenost u sljedeća tri mjeseca

Modaliteti: povećanje, ne mijenjanje, smanjenje

6OC - očekivana promjena cijena u sljedeća tri mjeseca

Modaliteti: povećanje, ne mijenjanje, smanjenje

Autor zahvaljuje Centru za poslovna istraživanja Privrednog vjesnika u Zagrebu na pravu korištenja podataka za provedeno empirijsko istraživanje. 


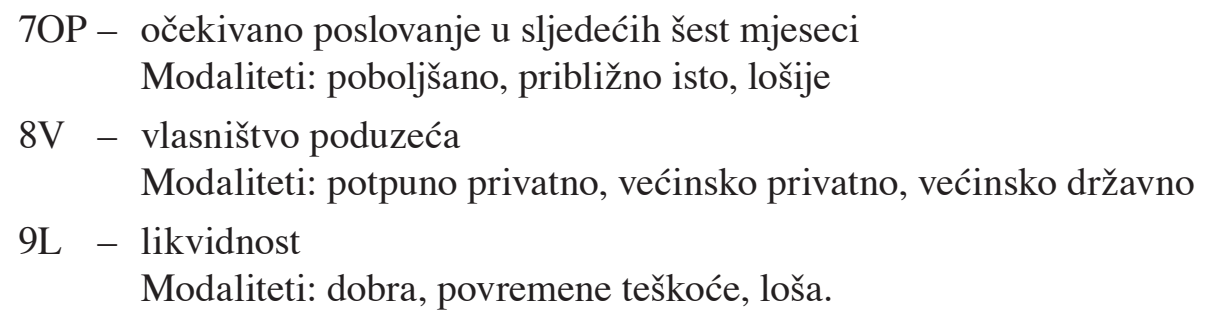

Prema Arnerić i Lolić (2015.) neparametarski testovi se koriste kada je oblik distribucije populacije, iz koje se izabire slučajni uzorak, nepoznat (engl. distribution free). Nultom hipotezom se može, iako ne mora, pretpostaviti vrijednost parametra distribucije nepoznatog oblika. Neparametarski testovi se mogu primijeniti pri analizi ne samo kvantitativnih varijabli (uz odgovarajuće prilagodbe) već i kvalitativnih varijabli, što je posebno važno u empirijskome istraživanju ovoga rada.

Kako bi se udovoljilo pretpostavci da očekivane frekvencije ne smiju biti manje od 5, združeni su modaliteti (i frekvencije) svih analiziranih varijabli na sljedeći način. Varijabla $8 \mathrm{~V}$ - vlasništvo poduzeća prezentirana je kroz dva modaliteta: „potpuno privatno“ i „osta10“ (što uključuje modalitete: ,većinsko privatno“ i „većinsko državno“). Za sve ostale varijable u testu dana su dva modaliteta: ,poboljšanje/povećanje“ i „ne mijenjanje i pogoršanje/ smanjenje“. Slijedom navedenoga, formirane su dvodimenzionalne distribucije frekvencija prezentirane u tablicama kontingence dimenzija $2 \times 2$.

U nultoj hipotezi je sadržana tvrdnja da su dvije varijable $X$ i $Y$ u tablici kontingence dimenzija 2 x 2 nezavisne, dok se u alternativnu hipotezu zapisuje njena sadržajna suprotnost (varijable nisu nezavisne). Ove hipoteze se uobičajeno zapisuju:

$$
\begin{aligned}
& H_{0}: p\left(x_{i}, y_{j}\right)=p\left(x_{i}\right) p\left(y_{j}\right) \forall i=1,2, \forall j=1,2 \\
& H_{1}: \exists i, j \quad p\left(x_{i}, y_{j}\right) \neq p\left(x_{i}\right) p\left(y_{j}\right),
\end{aligned}
$$

pri čemu $p\left(x_{i}, y_{j}\right), p\left(x_{i}\right), p\left(y_{j}\right)$ predstavljaju zajedničke vjerojatnosti i marginalne (granične) vjerojatnosti varijabli $X$ i $Y$. Zajedničke frekvencije $e_{i j}, i=1,2, j=1,2$ su očekivane frekvencije pod pretpostavkom istinite nulte hipoteze o nezavisnosti obilježja i računane su prema izrazu:

$$
e_{i j}=p\left(x_{i}\right) \cdot p\left(y_{j}\right) \cdot n
$$

pri čemu je $n$ veličina uzorka.

Temeljem stvarnih i očekivanih frekvencija izračunava se hi-kvadrat testna veličina, prema izrazu:

$$
\chi^{2}=\sum_{i=1}^{2} \sum_{j=1}^{2} \frac{\left(f_{i j}-e_{i j}\right)^{2}}{e_{i j}}
$$

pri čemu su $f_{i j}, e_{i j}, \quad i=1,2, \quad j=1,2$ stvarne i očekivane frekvencije u ćelijama $i j \mathrm{u}$ tablici kontingence dimenzija $2 \times 2$.

Hi-kvadrat testna veličina uspoređuje se s kritičnom (teorijskom) vrijednosti hi-kvadrat distribucije za 1 stupanj slobode (budući da se analiza provodi na tablici kontingence 
dimenzija 2 x 2). Nulta hipoteza se ne odbacuje ako je teorijska vrijednost manja od kritične vrijednosti hi-kvadrat distribucije. Isti se zaključak donosi ako je empirijska razina značajnosti ( $p$-vrijednost) veća od teorijske razine značajnosti $(\alpha)$.

U Prilogu A detaljno su prikazani rezultati provedenih statističkih testova. U tablicama kontingence (1. - 8.) prikazani su statistički nizovi nastali grupiranjem podataka prema modalitetima odabranih kvalitativnih varijabli. Jedna od dviju varijabli u svakoj tablici je vlasništvo. U gornjemu dijelu svakoga retka tablice dane su apsolutne frekvencije, dok su u donjemu dijelu dane proporcije kao relativne frekvencije. U svakoj tablici nalazi se hi-kvadrat testna veličina, kritična vrijednost hi-kvadrat distribucije za jedan stupanj slobode i teorijsku razinu značajnosti testa $5 \%$ koja je za sve provedene testove jednaka i iznosi 3,84146 te pripadajuća empirijska razina značajnosti ( $p$-vrijednost) za provođenje hi-kvadrat testa o nezavisnosti varijabli.

U tablici 3. prikazane su samo vrijednosti hi-kvadrat testnih veličina i pripadajuće $p$-vrijednosti za svih osam testova nezavisnosti varijabli.

Tablica 3. Hi-kvadrat testne veličine i p-vrijednosti hi-kvadrat testova o nezavisnosti varijable vlasništvo i ostalih varijabli u konjunkturnom testu uslužnoga sektora RH za drugo tromjesečje 2016. godine

\begin{tabular}{|l|c|c|c|c|}
\hline Varijable & 1PP & 2PP & 3OP & 4PZ \\
\hline Hi-kvadrat & 0.16168 & 0.39600 & 1.27395 & 0.06132 \\
\hline p-vrijednost & 0.68761 & 0.52916 & 0.25903 & 0.80443 \\
\hline Varijable & $5 \mathrm{OZ}$ & $6 \mathrm{OC}$ & $7 \mathrm{OP}$ & $9 \mathrm{~L}$ \\
\hline Hi-kvadrat & 0.00670 & 0.34685 & 0.35148 & 0.02263 \\
\hline p-vrijednosti & 0.93476 & $0.55590^{*}$ & 0.55328 & 0.88043 \\
\hline
\end{tabular}

Napomena: $p$-vrijednost (Fisherov test): 0.4353 (jednosmjerni); 0.7097 (dvosmjerni).

Rezultati provedenih hi-kvadrat testova dovode do jedinstvenoga zaključka. Za svaki od osam provedenih testova, hi-kvadrat testne veličine manje su od kritične vrijednosti hi-kvadrat distribucije za jedan stupanj slobode i teorijsku razinu značajnosti testa $5 \%$. Također, sve empirijske razine značajnosti ( $p$-vrijednosti) su veće od teorijske razine značajnosti 0,05 (5\%).

Nulta hipoteza o nezavisnosti varijabli se, uz razinu značajnosti $5 \%$ ne odbacuje, tj. ne odbacuje se pretpostavka da su analizirane varijable nezavisne. Stoga se zaključuje da su sve varijable u konjunkturnome testu u usporedbi s varijablom vlasništvo statistički nezavisne. Odnosno, vlasništvo ne određuje menadžerove ocjene i očekivanja vezane uz likvidnost, poslovanje, potražnju, cijene i zaposlenost. Iz navedenoga slijedi da u hrvatskome konjunkturnom testu uslužnoga sektora nije potrebno isključiti područja s državnim vlasništvom. Time će se osigurati veći obuhvat uslužnoga sektora i moći dobiti kvalitetniji zaključci o stanju i promjenama u uslužnome sektoru kao cjelini. 


\section{ZAKLJUČAK}

Konjunkturni testovi u EU provode se u četiri sektora od kojih je uslužni sektor vrlo heterogen, s nizom specifičnosti. Po harmoniziranome BCS programu nastoji se minimizirati utjecaj specifičnosti sektora na opće zaključke sektora kao cjeline. Tako se upravo u uslužnome sektoru provodi selekcija djelatnosti i njihovo isključivanje iz istraživanja ako značajno odstupaju od ostalih. Djelatnosti u kojima je dominantno javno vlasništvo i u kojima su ocjene i očekivanja menadžera velikim dijelom unaprijed određena raznim regulativama, a manje su odraz njihovih stvarnih percepcija stanja u okruženju i planova za promjene, uglavnom su djelatnosti javnih usluga. Zbog toga se sugerira te djelatnosti isključiti iz istraživanja ili provesti zasebna istraživanja samo u tim djelatnostima.

U radu je provedeno empirijsko istraživanje u uslužnome sektoru Hrvatske. Hi-kvadrat testom ispitana je istraživačka hipoteza rada da su vlasništvo (s jedne strane) i sve ostale varijable u tromjesečnome konjunkturnom testu uslužnoga sektora RH (s druge strane) statistički nezavisne varijable. Hipoteza je potvrđena te se zaključuje da nije nužno iz hrvatskoga konjunkturnog testa isključiti područja u kojima su značajno zastupljena poduzeća s državnim vlasništvom kao što su obrazovanje i djelatnost zdravstvene zaštite i socijalne skrbi.

Nekoliko je ograničenja istraživanja čije uklanjanje predstavlja ujedno i daljnje planirane smjernice istraživanja. Statistički testovi primijenjeni su na uzorku 90 jedinica koliko ih je sudjelovalo u konjunkturnome testu Privrednog vjesnika za drugo tromjesečje 2016. godine. Zbog niske stope odgovora, uzorak je relativno malen. Iako je u uzorku bilo dovoljno jedinica da se ispravno provedu odgovarajući statistički testovi, veći uzorak zasigurno bi pridonio kvaliteti zaključivanja. Osim toga, istraživanje je provedeno u drugome tromjesečju 2016. godine. Isto bi trebalo ponoviti u još nekoliko tromjesečja i usporediti rezultate odnosno provjeriti mijenjaju li se zaključci u različitim vremenskim intervalima (tromjesečjima).

Napomena: Rad je financirala Hrvatska zaklada za znanost projektom broj IP-11-2013-3858.

\section{LITERATURA:}

1. Astolfi, M. et al. (2016). The use of short-term indicators and survey data for predicting turning points in economic activity: a performance analysis of the OECD system of CLIs during the great recession, OECD Statistics Working Papers, 2016/07, OECD Publishing, Paris.

2. Arnerić, J. i Lolić, I. (2015). Hi-kvadrat test (u Bahovec i dr.), Element. Zagreb.

3. Antonides, G. (2008). How is perceived inflation related to actual price changes in the European Union? Journal of Economic Psychology, 29(4), 417-432.

4. Baláž, V. i Nežinský, E. (2016). Are the Confidence Indicators Meaningful for Forecasting Real Economy?, Ekonomický časopis, 64(10), 923-936.

5. Cesaroni, T. i Iezzi, S. (2015). The Predictive Content of Business Survey Indicators: Evidence from SIGE (September 22, 2015). Bank of Italy Temi di Discussione (Working Paper) No. 1031. SSRN: https://ssrn.com/abstract=2722518. 
6. Claveria, O., Pons, E. i Ramos, R. (2005). Business and Consumer Expectations and Macroeconomic Forecasts, Proceedings of Conference on Survey data in Economics Methodology and Applications - Cess IFO, Munich: 1-20.

7. DGECFIN (2017) December 2016: Economic Sentiment improves strongly in both the euro area and the EU, https://ec.europa.eu/info/business-economy-euro/indicators-statistics/economic-databases/business-and-consumer-surveys/latest-business-and-consumer-surveys_en [pristupano 27. 1. 2017.].

8. Čižmešija, M. (2008.). Konjunkturni testovi Europske unije i Hrvatske, Privredni vjesnik, Zagreb.

9. Čižmešija, M. (2016.). Bez značajnijih promjena do jeseni. Konjunkturni test za II. tromjesečje 2016., Privredni vjesnik 3937/3938, str. 22-25., 18. srpnja 2016.

10. European Commission (2017a) The Joint Harmonised EU Programme of Business and Consumer Surveys, User guide, 02/2017., dostupno na :http://ec.europa.eu/economy_ finance/db_indicators/surveys/documents/bcs_user_guide_en.pdf [pristupano 13. 4. 2017.].

11. European Commision (2017b). Services_total_sa_nace2, https://ec.europa.eu/info/ business-economy-euro/indicators-statistics/economic-databases/business-and-consumer-surveys [pristupano 13. 1. 2017.].

12. European Commission (1997). The joint harmonised EU programme of business and consumer surveys, Directorate-General for Economic and Financial Affairs. Luxembourg.

13. Eurostat (2008). NACE Rev 2. Statistical Classification of economic activities in the European Community, European Commission. Luxembourg.

14. Lehmann, R. i Wohlrabe, K. (2016). Experts, firms, consumers or even hard data? Forecasting employment in Germany. MPRA Paper No. 69611, Online https://mpra. ub.uni-muenchen.de/69611/ [pristupano 13. 4. 2017.].

15. Papamichael, C. i Pashourtidou, N. (2016). The Role of Survey Data in the Construction of Short-term GDP Growth Forecasts, Cyprus Economic Policy Review, 10(2), pp. 77-109 (2016).

16. Priopćenje DZS-a 12.1.4/30. rujna 2016. http://www.dzs.hr [pristupano 13. 1. 2017.].

17. Privredni vjesnik, Centar za poslovna istraživanja (pristup podacima). 
PRILOG A

Tablica 1. Ocijenjeno poslovanje u prethodna tri mjeseca i vlasništvo

\begin{tabular}{|c|c|c|c|}
\hline${ }_{1 \mathrm{PP}}^{8 \mathrm{~V}}$ & Potpuno privatno & Ostalo & Ukupno \\
\hline Poboljšanje & $\begin{array}{c}46 \\
0.51111\end{array}$ & $\begin{array}{c}23 \\
0.25556\end{array}$ & $\begin{array}{c}69 \\
0.76667\end{array}$ \\
\hline Ne mijenjanje i pogoršanje & $\begin{array}{c}13 \\
0.14444\end{array}$ & $\begin{array}{c}8 \\
0.08889\end{array}$ & $\begin{array}{c}21 \\
0.23333\end{array}$ \\
\hline Ukupno & $\begin{array}{c}59 \\
0.65555 \\
\end{array}$ & $\begin{array}{c}31 \\
0.34445 \\
\end{array}$ & $\begin{array}{c}90 \\
1.00000 \\
\end{array}$ \\
\hline Hi-kvadrat & \multicolumn{3}{|l|}{0.16168} \\
\hline Hi-kvadrat $(d f=1 ; \alpha=0.05)$ & \multicolumn{3}{|l|}{3.84146} \\
\hline$p$-vrijednost & \multicolumn{3}{|l|}{0.68761} \\
\hline
\end{tabular}

Izvor: izračun autora.

Tablica 2. Ocijenjena potražnja u prethodna tri mjeseca i vlasništvo

\begin{tabular}{|c|c|c|c|}
\hline${ }_{2 \mathrm{PP}}^{8 \mathrm{~V}}$ & Potpuno privatno & Ostalo & Ukupno \\
\hline Povećanje & $\begin{array}{c}43 \\
0.44444\end{array}$ & $\begin{array}{c}23 \\
0.25556\end{array}$ & $\begin{array}{c}63 \\
0.70000\end{array}$ \\
\hline Ne mijenjanje i smanjenje & $\begin{array}{c}13 \\
0.21111\end{array}$ & $\begin{array}{c}8 \\
0.08889\end{array}$ & $\begin{array}{c}21 \\
0.30000\end{array}$ \\
\hline Ukupno & $\begin{array}{c}59 \\
0.65555 \\
\end{array}$ & $\begin{array}{c}31 \\
0.34445\end{array}$ & $\begin{array}{c}90 \\
1.00000\end{array}$ \\
\hline Hi-kvadrat & \multicolumn{3}{|l|}{0.39600} \\
\hline Hi-kvadrat $(d f=1 ; \alpha=0.05)$ & \multicolumn{3}{|l|}{3.84146} \\
\hline$p$-vrijednost & \multicolumn{3}{|l|}{0.52916} \\
\hline
\end{tabular}

Izvor: izračun autora.

Tablica 3. Očekivana potražnja u sljedeća tri mjeseca i vlasništvo

\begin{tabular}{|l|c|c|c|}
\hline 3OP & Potpuno privatno & Ostalo & Ukupno \\
\hline Povećanje & 43 & 19 & 62 \\
& 0.47778 & 0.21111 & 0.68889 \\
\hline \multirow{2}{*}{ Ne mijenjanje i smanjenje } & 16 & 12 & 28 \\
& 0.17778 & 0.13333 & 0.31111 \\
\hline \multirow{2}{*}{ Ukupno } & 59 & 31 & 90 \\
& 0.65556 & 0.34444 & 1.00000 \\
\hline Hi-kvadrat & 1.27395 & \\
\hline Hi-kvadrat $(d f=1 ; \alpha=0.05)$ & 3.84146 & \\
\hline$p$-vrijednost & 0.25903 & \\
\hline
\end{tabular}

Izvor: izračun autora. 
Tablica 4. Ocjena zaposlenosti u prethodna tri mjeseca i vlasništvo

\begin{tabular}{|c|c|c|c|}
\hline $\mathrm{SPZ}_{4 \mathrm{PZ}}^{8 \mathrm{~V}}$ & Potpuno privatno & Ostalo & Ukupno \\
\hline Povećanje & $\begin{array}{c}47 \\
0.52222\end{array}$ & $\begin{array}{c}24 \\
0.26667\end{array}$ & $\begin{array}{c}71 \\
0.78889\end{array}$ \\
\hline Ne mijenjanje i smanjenje & $\begin{array}{c}12 \\
0.13333\end{array}$ & $\begin{array}{c}7 \\
0.07778\end{array}$ & $\begin{array}{c}19 \\
0.21111\end{array}$ \\
\hline Ukupno & $\begin{array}{c}59 \\
0.65555 \\
\end{array}$ & $\begin{array}{c}31 \\
0.34445\end{array}$ & $\begin{array}{c}90 \\
1.00000\end{array}$ \\
\hline Hi-kvadrat & \multicolumn{3}{|l|}{0.06132} \\
\hline Hi-kvadrat $(d f=1 ; \alpha=0.05)$ & \multicolumn{3}{|l|}{3.84146} \\
\hline$p$-vrijednost & \multicolumn{3}{|l|}{0.80443} \\
\hline
\end{tabular}

Izvor: izračun autora.

Tablica 5. Očekivana zaposlenost u sljedeća tri mjeseca i vlasništvo

\begin{tabular}{|c|c|c|c|}
\hline${ }_{50 \mathrm{Z}}^{8 \mathrm{~V}}$ & Potpuno privatno & Ostalo & Ukupno \\
\hline Povećanje & $\begin{array}{c}48 \\
0.53333 \\
\end{array}$ & $\begin{array}{c}25 \\
0.27778 \\
\end{array}$ & $\begin{array}{c}73 \\
0.81111\end{array}$ \\
\hline Ne mijenjanje i smanjenje & $\begin{array}{c}11 \\
0.12222 \\
\end{array}$ & $\begin{array}{c}7 \\
0.06667 \\
\end{array}$ & $\begin{array}{c}17 \\
0.18889\end{array}$ \\
\hline Ukupno & $\begin{array}{c}59 \\
0.65555 \\
\end{array}$ & $\begin{array}{c}31 \\
0.34445 \\
\end{array}$ & $\begin{array}{c}90 \\
1.00000 \\
\end{array}$ \\
\hline Hi-kvadrat & \multicolumn{3}{|l|}{0.00670} \\
\hline Hi-kvadrat $(d f=1 ; \alpha=0.05)$ & \multicolumn{3}{|l|}{3.84146} \\
\hline$p$-vrijednost & \multicolumn{3}{|l|}{0.93476} \\
\hline
\end{tabular}

Izvor: izračun autora.

Tablica 6. Očekivana promjena cijena u sljedeća tri mjeseca i vlasništvo

\begin{tabular}{|c|c|c|c|}
\hline${ }_{60 \mathrm{C}}^{8 \mathrm{~V}} 8 \mathrm{~V}$ & Potpuno privatno & Ostalo & Ukupno \\
\hline Povećanje & $\begin{array}{c}53 \\
0.58889 \\
\end{array}$ & $\begin{array}{c}29 \\
0.32222 \\
\end{array}$ & $\begin{array}{c}82 \\
0.91111\end{array}$ \\
\hline Ne mijenjanje i smanjenje & $\begin{array}{c}6 \\
0.06667 \\
\end{array}$ & $\begin{array}{c}2 \\
0.02222 \\
\end{array}$ & $\begin{array}{c}8 \\
0.18889\end{array}$ \\
\hline Ukupno & $\begin{array}{c}59 \\
0.65556 \\
\end{array}$ & $\begin{array}{c}31 \\
0.34444\end{array}$ & $\begin{array}{c}90 \\
1.00000\end{array}$ \\
\hline Hi-kvadrat & \multicolumn{3}{|l|}{0.34685} \\
\hline Hi-kvadrat $(d f=1 ; \alpha=0.05)$ & \multicolumn{3}{|l|}{3.84146} \\
\hline$p$-vrijednost & \multicolumn{3}{|c|}{0.55590} \\
\hline$p$-vrijednost (Fisherov test) & \multicolumn{3}{|c|}{0.4353 (jednosmjerni); 0.7097 (dvosmjerni) } \\
\hline
\end{tabular}

Izvor: izračun autora.

Napomena: Budući da je očekivana frekvencija $e_{22}=2,76$ i manja je od 5, narušena je pretpostavka očekivane frekvencije ne manje od 5. U tome slučaju proveden je Fisherov test. 
Tablica 7. Očekivano poslovanje u sljedećih šest mjeseci i vlasništvo

\begin{tabular}{|l|c|c|c|}
\hline 70P & Potpuno privatno & Ostalo & Ukupno \\
\hline Poboljšanje & 12 & 8 & 20 \\
& 0.13333 & 0.08889 & 0.22222 \\
\hline Približno isto i lošije & 47 & 23 & 17 \\
& 0.52222 & 0.25556 & 0.18888 \\
\hline Ukupno & 59 & 31 & 90 \\
& 0.65555 & 0.34445 & 1.00000 \\
\hline Hi-kvadrat & 0.35148 & \\
\hline Hi-kvadrat $(d f=1 ; \alpha=0.05)$ & 3.84146 & \\
\hline$p$-vrijednost & 0.55328 & \\
\hline
\end{tabular}

Izvor: izračun autora.

Tablica 8. Ocjena likvidnosti i vlasništvo

\begin{tabular}{|l|c|c|c|}
\hline 9L & Potpuno privatno & Ostalo & Ukupno \\
\hline Dobra & 39 & 20 & 20 \\
& 0.43333 & 0.22222 & 0.65555 \\
\hline Povremene teškoće i loša & 20 & 11 & 31 \\
& 0.22222 & 0.12223 & 0.34445 \\
\hline Ukupno & 59 & 31 & 90 \\
& 0.65555 & 0.34445 & 1.00000 \\
\hline Hi-kvadrat & 0.02263 & \\
\hline Hi-kvadrat $(d f=1 ; \alpha=0.05)$ & 3.84146 & \\
\hline$p$-vrijednost & 0.88043 & \\
\hline
\end{tabular}

Izvor: izračun autora. 